\title{
PERBANDINGAN NILAI TAMBAH DAN KEUNTUNGAN PENGOLAHAN PRODUK KEDELAI DI UD TIGA BERSAUDARA DI KELURAHAN TAAS KECAMATAN TIKALA
}

\author{
Dicky Ocniel Aji Samuna \\ Nordy Fritsgerald Lucky Waney \\ Agnes Estephina Loho
}

\begin{tabular}{ll}
\hline Naskah diterima melalui Website Jurnal Ilmiah agrisosioekonomi@unsrat.ac.id & : Jumat, 10 Januari 2020 \\
Disetujui diterbitkan & : Senin, 13 Januari 2020 \\
\hline
\end{tabular}

\begin{abstract}
The purpose of this study is to find out how much added value and benefits are, and to compare the added value of three soybean processing products at UD Tiga Brothers into tofu, sugar tofu and soy milk. This research lasted for 3 months, from April until June 2019. Data used in this study are primary and secondary data. Primary data were obtained from direct interviews from the UD Tiga Brothers factory owner, observations and records. The analysis used in this research is to use value added analysis, profit analysis, and compare the added value of the three soybean processing products.The results of this study indicated that the added value of processing soybeans into Chinese tofu is Rp. 37,749 / kg, the added value of processing soybeans into soy milk is Rp. 31,468/ kg and the added value of processing soybeans into tofu sugar is $R p .40,942 .-/ \mathrm{kg}$. while the benefits of processing soybeans into Chinese tofu amounted to Rp. 377,991/ kg, the profit from processing soybeans to soy milk is $R p$. 33,464,5 - / $\mathrm{kg}$ and the profit from processing soybeans to tofu sugar is $R p .68,140 / \mathrm{kg}$. Therefore it can be conclude the highest added value is tofu sugar product while the highest profit is chinese tofu products. ${ }^{*}$ prm*
\end{abstract}

Keywords: comparison, value added, benefits, processing of soy products

ABSTRAK

Tujuan dari penelitian ini adalah untuk mengetahui berapa besar nilai tambah dan keuntungan, serta untuk membandingkan nilai tambah dari tiga produk hasil pengolahan kedelai di UD Tiga Bersaudara menjadi tahu, tahu gula, dan susu kedelai.. Penelitian ini berlangsung selama 3 bulan, dari bulan April sampai Juni 2019. Data yang digunakan dalam penelitian ini adalah data primer dan sekunder. Data primer diperoleh dari wawancara langsung dari pemilik pabrik UD Tiga Bersaudara, pengamatan dan pencatatan. Analisis yang digunakan dalam penelitian ini adalah menggunakan analisis nilai tambah, analisis keuntungan, dan yaitu untuk mengkaji dan membandingkan nilai tambah dari ketiga produk pengolahan kedelai. Hasil penelitian ini menunjukkan bahwa nilai tambah dari pengolahan kedelai menjadi tahu cina sebesar Rp. 38.354,-/kg, nilai tambah pengolahan kedelai menjadi susu kedelai sebesar Rp. 30.806,-/kg dan nilai tambah pengolahan kedelai menjadi tahu gula sebesar Rp. 40.987,-/kg. Keuntungan pengolahan kedelai menjadi tahu cina sebesar Rp. 33.668,-/kg, keuntungan pengolahan kedelai menjadi susu kedelai sebesar Rp. 12.363,-/kg dan keuntungan pengolahan kedelai menjadi tahu gula sebesar Rp. 22.758,-/kg. Maka dapat di simpulkan nilai tambah tertinggi adalah pada produk tahu gula sedangkan keuntungan tertinggi adalah pada produk tahu cina. *eprm*

Kata kunci: perbandingan, nilai tambah, keuntungan, pengolahan produk kedelai

Agrisosioekonomi:

Jurnal Transdisiplin Pertanian (Budidaya Tanaman, Perkebunan, Kehutanan, Peternakan, Perikanan), Sosial dan Ekonomi 


\section{PENDAHULUAN}

Olahan produk kedelai berpotensi dan berperan dalam menumbuh kembangkan industri kecil menengah bahkan berpeluang pula sebagai komuditas ekspor. Berkembanganya industri berbahan baku kedelai membuka peluang kesempatan kerja dalam sistem produksi, mulai dari budidaya, pengolahan, panen, pasca panen, transpotasi, hingga industri pengolahan pangan. Agar produksi kedelai mampu bersaing di pasar maka mutunya perlu di tingkatkan.

Pengolahan hasil pertanian merupakan komponen kedua dari kegiatan agribisnis setelah proses produksi hasil pertanian. Komponen hasil pertanian menjadi penting karena pertimbangan meningkatkan nilai tambah, meningkatkan kualitas hasil, meningkatkan penyerapan tenaga kerja, menigkatkan keterampilan produsen dan meningkatkan pendapatan produsen (Soekartawi, 1995).

Nilai tambah adalah pertambahan nilai suatu produk atau komoditas karena mengalami proses pengolahan, pengangkutan, ataupun penyimpanan dalam suatu produksi. Dalam proses pengolahan nilai tambah dapat didefinisikan sebagai selisih antara nilai produk dengan nilai bahan baku dan input lainya, tidak termasuk tenaga kerja.

Salah satu faktor yang mempengaruhi nilai tambah adalah penyusutan yaitu biaya pergantian untuk keausan dan kelapukan modal dalam produksi. Penyusutan dalam arti ini yaitu kosumsi modal dan pemakaian modal. Dengan memperhatikan penyusutan tersebut, ada dua konsep nilai tambah yaitu nilai tambah netto dan nilai tambah bruto. Nilai tambah netto adalah nilai yang memperhitungan penyusutan yang terjadi, sedangkan nilai tambah bruto adalah nilai yang tidak memperhitungkan penyusutan (Sicat dan Arndt, 1991).

Kedelai merupakan bahan pangan sumber protein nabati yang paling murah sehingga kebutuhan kedelai untuk pangan mencapai $95 \%$ dari total kebutuhan kedelai di Indonesia. Biji kedelai mempunyai nilai guna yang cukup tinggi karena bisa di manfaatkan sebagai bahan pangan, pakan, bahan baku industri, baik skala kecil maupun skala besar. Produk pangan berbahan baku kedelai ini dapat di bagi menjadi dua kategori, yaitu dalam bentuk nonfermentasi dan fermentasi. Hasil nonfermentasi berupa kedelai rebus, bubuk kedelai, susu kedelai. Sedangkan hasil fermentasi berupa tempe dan kecap (Adisarwanto, 2005).
Kedelai sebagian besar tumbuh di daerah beriklim tropis dan subtropis. Kedelai dapat bertumbuh baik di tempat berhawa panas, di tempat yang terbuka dan bercurah hujan berkisar antara 100-400 milimeter kubik per bulan. Kedelai kebanyakan ditanam di daerah yang terletak 600 meter dari permukaan laut. Tanaman ini bertumbuh baik pada berbagai jenis tanah asal drainasenya cukup baik.

UD Tiga Bersaudara merupakan salah satu industri yang mengolah kedelai menjadi tahu cina, tahu gula dan susu kedelai. Lokasi industri ini terletak di kelurahan Taas Kecamatan Tikala. Industri ini mulai memproduksi tahun 1982. UD Tiga Bersaudara perlu teliti karena sudah beroperasi cukup lama sehingga perlu lihat proses pengolahannya karena alat yang di gunakan untuk pengolahan masih tergolong sederhana dan perlu dikaji nilai tambah dari usaha rumah tangga ini agar supaya bisa ketahui produk mana yang harus dikembangkan dan mana yang harus pertahankan.

\section{Rumusan Masalah}

Berdasarkan latar belakang dikemukakan, maka yang menjadi permasalahan dalam penelitian ini adalah

1. Berapa besar nilai tambah yang dihasilkan dari pengolahan kedelai menjadi tahu gula, menjadi tahu cina, dan menjadi susu kedelai?

2. Berapa besar keuntungan dari usaha pengolahan kedelai menjadi susu kedelai, menjadi tahu cina dan menjadi tahu gula?

3. Bagaimana perbandingan nilai tambah dan keuntungan dari pengolahan kedelai menjadi tahu gula, menjadi tahu dan menjadi susu kedelai?

\section{Tujuan penelitian}

Berdasarkan identifikasi masalah, maka tujuan penelitian adalah sebagai berikut:

1. Untuk mengkaji nilai tambah yang di peroleh dari pengolahan kedelai menjadi susu kedelai, menjadi tahu cina, dan menjadi tahu gula

2. Untuk mengetahui keuntungan dari usaha pengolahan kedelai menjadi tahu gula, menjadi tahu cina dan menjadi susu kedelai

3. Untuk membandingkan nilai tambah dan keuntungan dari usaha pengolahan kedelai menjadi tahu gula, menjadi tahu cina, dan menjadi susu kedelai 


\section{Manfaat Penelitian}

Hasil penelitian ini diharapkan dapat berguna:

1. Bagi pihak industri UD Tiga Bersudara pada khususnya diharapkan penelitian ini dapat membuka wawasan dan memberikan gambaran dalam pengembangan usahanya.

2. Bagi peneliti, diharapkan dapat menambah wawasan dan pengetahuan mengenai nilai tambah produk kedelai.

3. Bagi pihak lain, diharapkan dapat menjadi informasi, serta dapat digunakan dalam penerapan konsep dan teori-teori pada penelitian dibidang yang sama.

\section{METODE PENELITIAN}

\section{Lokasi dan Waktu Penelitian}

Penelitian ini akan di laksanakan pada UD Tiga Bersaudara yang lokasinya berada di Kelurahan Taas Kecamatan Tikala. Penelitiaan ini akan dilaksanakan selama 3 bulan dari bulan April- juni 2019.

\section{Teknik Pengumpulan Data}

Teknik pengumpulan Data ada 3 cara yang di gunakan yaitu

(1) teknik Observasi adalah teknik pengumpulan data yang mengadakan pengamatan langsung di lapangan terhadap objek yang di teliti,

(2) teknik wawancara merupakan teknik pengumpulan data yang di lakukan dengan cara Tanya jawab dengan responden dan

(3) teknik pencatatan merupakan teknik pengumpulan data yang dilakukan dengan cara mencatat hasil wawancara pada daftar pertanyaan (kuesioner).

\section{Jenis dan Sumber Data}

Data yang di kumpulkan dalam penelitian ini terdiri atas data primer dan data sekunder. Data primer adalah data yang di ambil oleh peneliti di lapangan langsung dari sumbernya yaitu pemilik pabrik Tiga Bersaudara di Kelurahan Taas Kecamatan Tikala. Sedangkan data sekunder merupakan data yang di peroleh dari berbagai literatur yang terkait dengan penelitian ini.

\section{Konsep Pengukuran variable}

Variabel-variabel yang diukur serta digunakan dalam penelitian ini adalah :

1) Biaya yang dikeluarkan untuk memproduksi tahu cina, susu kedelai, tahu gula meliputi:

a. Biaya bahan baku adalah biaya yang dikeluarkan untuk pembelian bahan baku untuk pengolahan produk tahu cina, susu kedelai dan tahu gula.

b. Biaya bahan penolong adalah biaya yang dikeluarkan untuk membeli bahan penolong untuk pengolahan produk tahu cina, susu kedelai dan tahu gula.

c. Biaya peralatan adalah biaya yang dikeluarkan untuk membeli peralatan yang digunakan untuk pengolahan tahu cina, susu kedelai dan tahu gula.

d. Biaya tenaga kerja adalah biaya yang di keluarkan untuk tenaga kerja untuk proses pengolahan tahu cina, susu kedelai dan tahu gula.

2) Input yaitu bahan baku, bahan penolong dan peralatan yang digunakan untuk menghasilkan produk tahu cina, susu kedelai dan tahu cina.

3) Harga Output yaitu harga penjualan tahu cina, susu kedelai dan tahu gula di tempat penjualan ( $\mathrm{Rp})$

4) Harga Input yaitu harga pembelian bahan baku, bahan penolong dan peralatan di UD Tiga Bersaudara (Rp)

5) Tenaga Kerja yaitu jumlah tenaga kerja yang terlibat dalam proses pengolahan kedelai menjadi produk tahu cina, susu kedelai dan susu kedelai.

6) Upah tenaga kerja yaitu banyaknya upah yang di bayar kepada tenaga kerja yang terlibat dalam proses produksi tahu cina, susu kedelai dan tahu gula (Rp/hari)

\section{Metode Analisis Data}

Analisis yang digunakan dalam penelitian ini adalah menggunakan analisis nilai tambah yaitu untuk mengkaji dan membandingkan nilai tambah yang diperoleh dari pengolahan kedelai menjadi tahu, tahu gula, dan susu kedelai. Data yang dikumpulkan akan disajikan dalam bentuk tabel dan dianalisis secara deskriptif. Rumus yang digunakan menurut Zukifli (2012), yaitu: 


$$
\begin{aligned}
\mathrm{NTp} & =\mathrm{Na}-(\mathrm{Bb}+\mathrm{Bp}+\mathrm{Bbp}) \\
& =\mathrm{Na}-\mathrm{Ba}
\end{aligned}
$$

Keterangan : $\quad \mathrm{NTp}=$ Nilai tambah Produk $(\mathrm{Rp})$ produk kedelai $(\mathrm{Rp})$

$$
\mathrm{Na}=\text { Nilai produk akhir dari tiga }
$$

$\mathrm{Ba}=$ Biaya antara $(\mathrm{Rp})$

$\mathrm{Bb}=$ Biaya bahan baku (Rp)

$\mathrm{Bp}=$ Biaya peralatan $(\mathrm{Rp})$

$\mathrm{BBp}=$ Biaya bahan penolong (Rp)

Menghitung penerimaan dapat dihitung dengan mengunakan rumus menurut Soekartawi (1995) yaitu :

$$
\mathrm{TR}=\mathrm{Q} \times \mathrm{P}
$$

Keterangan :

$\mathrm{TR}=$ Penerimaan total produk tahu gula, tahu cina dan susu kedelai

Q = Jumlah produk tahu gula, tahu cina dan susu kedelai

$\mathrm{P} \quad=$ Harga produk tahu gula, tahu cina dan susu kedelai

Untuk mengetahui keuntungan dari produk tahu gula, tahu cina dan susu kedelai mengunakan rumus menurut Lipsey et all (1990) yaitu:

$$
\pi=\mathrm{TR}-\mathrm{TC}
$$

\section{Keterangan:}

$\pi=$ Keuntungan pengolahan kedelai menjadi tahu gula, tahu cina dan susu kedelai

TR = Penerimaan pengolahan kedelai menjadi tahu gula, tahu cina dan susu kedelai

TC = Biaya total pengolahan kedelai menjadi tahu gula, tahu cina dan susu kedelai.

\section{HASIL DAN PEMBAHASAN}

\section{Gambaran Umum UD. Tiga Bersaudara}

UD. Tiga Bersaudara merupakan salah satu industri rumah tangga dimana tenaga kerjanya adalah anggota keluarga. Industri ini terletak di Kelurahan Taas Kecamatan Tikala. Industri ini mulai beroperasi sejak tahun 1982 dan bertahan hingga saat ini. Pada awal industri ini beroperasi, industri ini belum memiliki nama dan izin usaha.
Awalnya pemilik industri ini adalah orang tua (Almarhum) dari ibu Beatris Maradesa. Pada tahun 2000 industri ini di wariskan kepada ibu Beatris Maradesa dan Bapak Spener Duitan. Pada saat industri ini di kelola oleh Bapak Spener dengan Ibu Beatris, industri ini di daftakan ke Departemen Kesehatan dan Departemen Perindustrian dan Perdagangan. UD. Tiga Bersaudara sekarang telah terdafatar secara resmi di Departemen Kesehatan RI dengan No:SP.1155/1801/2000. Dan pada tahun 2008 industri ini, telah terdafatar pada Departemen Perdagangan dan Departemen Perindustrian dengan NO:TDT.062/D.09/Perindag /Ind/12.00.01./VI/2008.

\section{Proses Pengolahan Produk Kedelai Pada UD Tiga Bersaudara}

UD Tiga Bersaudara terletak di Kelurahan Taas Kecamatan Tikala telah memproduksi tiga produk olahan kedelai yaitu tahu gula, tahu cina dan susu kedelai. Proses pengolahan usaha pengolahan kedelai tergolong sangat sederhana, tetapi hasil produk olahan kedelai tersebut mempunyai pangsa pasar yang tetap sehingga menarik perhatian untuk di ketahui bagaimana proses pengolahannya dari awal sampai tahap produksi.

\section{Deskripsi Produk Pengolahan Kedelai}

a. Produk tahu cina

Tahu cina merupakan bahan makanan yang cukup di gemari dikalangan masyarakat khususnya di Sulawesi utara. Tahu cina tidak hanya bergizi tapi juga sebagai sumber protein bagi kesehatan tubuh manusia. Tahu cina terbuat dari sari kedelai yang diolah sehingga menghasilkan tahu yang kita konsumsi sehari- sehari. Tahu cina pada umumnya memiliki warna putih dan tekstur yang padat halus dan kenyal. Tahu cina berukuran lebih besar dibandingkan dengan tahu lainnya.

b. Produk susu kedelai

Susu kedelai adalah minuman yang bergizi berbentuk cair, berwarna putih dan rasanya manis seperti susu pada umumnya. Susu kedelai adalah salah satu hasil pengolahan hasil ekstrasi dari kedelai. Protein susu kedelai hampir sama dengan susu sapi sehingga susu kedelai seringkali digunakan sebagai pengganti susu sapi bagi mereka yang alergi terhadap hewani. 
c. Tahu gula adalah salah satu olahan kedelai yang berprotein tinggi. Tahu gula adalah sejenis makanan kaya protein yang memiliki tekstur seperti puding namun lebih lunak yang biasa disajikan dengan larutan gula merah dan air jahe.

\section{Persediaan Bahan baku}

Bahan baku merupakan bahan yang sangat penting dalam proses pengolahan. Maka ketersediaan bahan baku merupakan salah satu kunci keberhasilan pada pabrik dalam memproduksi. Pada pabrik UD Tiga Bersaudara bahan baku yang disediakan pada pengolahan tiga produk yaitu tahu cina, susu kedelai dan tahu gula hanya kacang kedelai. Kacang kedelai di beli dari salah satu toko yang berada di Perkamil yang sudah menjadi langganan dari pemilik industri. Kacang kedelai yang biasa digunakan adalah kacang kedelai berasal dari Surabaya. Menurut pemilik industri, kacang kedelai yang berasal dari Surabaya memiliki kualitas yang sangat bagus. Untuk pembelian kacang kedelai biasanya untuk satu minggu dua kali pembelian, sehingga sekali beli 50 $\mathrm{kg}$ kacang kedelai jadi bahan baku yang di sediakan dalam seminggu $100 \mathrm{~kg}$ kedelai dengan harga per $1 \mathrm{Kg}$ kedelai sebesar Rp.10.000.

\section{Persediaan Bahan Penolong}

Bahan penolong adalah bahan yang digunakan untuk suatu produk namun bukan merupakan bagian dari bahan baku utama. Bahan penolong yang digunakan pada pengolahan produk kedelai pada UD Tiga Bersaudara adalah untuk produk tahu cina (batu tahu, dan air), untuk produk susu kedelai (gula pasir,daun pandan dan air) dan untuk produk tahu gula (jahe, batu tahu, gula merah dan air). Batu tahu berfungsi untuk mengeraskan sari kedelai sehingga menjadi tahu, gula putih berfungsi sebagai larutan susu kedelai agar rasa dari susu kedelai manis, dan fungsi dari jahe dan gula merah sama karena sama-sama sebagai larutan tahu gula pada saat disajikan. Bahan penolong pada pengolahan kedelai dari tiga produk tersebut lebih jelas diuraikan sebagai berikut.

1. Batu tahu

Bahan penolong seperti batu tahu, pemilik industri memperolehnya dari toko yang berada ditikala. Untuk pembelian batu tahu dilakukan tiga bulan sekali sebanyak 1 Kg dengan harga Rp. 12.000. Bahan penolong batu tahu digunakan untuk pengolahan tahu cina dan tahu gula. Pengunaan batu tahu dalam sekali produksi pada pengolahan tahu cina 5 sendok makan per ember sari kedelai sedangkan untuk tahu gula 3 sendok makan.

2. Gula pasir

Bahan penolong seperti gula pasir, pemilik industri memperolehnya dari toko-toko terdekat yang berada di tikala. Untuk pembelian gula pasir dilakukan setiap hari. Pengunaan gula pasir dalam sekali produksi $1 \mathrm{~kg}$, dengan harga per $1 \mathrm{Kg}$ yaitu, Rp. 12.000 .

3. Gula merah

Bahan penolong seperti gula merah, pemilik industri memperolehnya dari pasar karombasan. Untuk pembelian gula merah dilakukan 3 hari sekali sebanyak $2 \mathrm{Kg}$ dengan harga per $1 \mathrm{Kg}$ yaitu, Rp. 30.000. Pengunaan gula merah dalam 1 kali produksi $2 \mathrm{Kg}$.

4. Jahe

Bahan penolong seperti jahe, pemilik industri memperolehnya dari pasar karombasan. Untuk pembelian jahe dilakukan 3 hari sekali sebanyak $1 \mathrm{Kg}$ dengan harga per 1 Kg yaitu, Rp. 70.000. Pengunaan jahe dalam 1 kali produksi $1 \mathrm{Kg}$.

5. Daun padan

Bahan penolong seperti daun padan, pemilik industri memperolehnya dari halaman rumahnya, bila daun pandan yang digunakan dalam produksi ini di uangkan maka, pemilik industri harus mengeluarkan biaya sebesar Rp. 2.000 per ikat $/ 5$ lembar. Pengunaan daun pandan 1 kali produksi 5 lembar.

6. Air

Bahan penolong seperti air, pemilik industri memperolehnya dari sumur mereka sendiri, bila air yang digunakan dalam produksi ini di uangkan maka, pemilik industri harus mengeluarkan biaya sebesar Rp. 5.000 per 19 liter. Pengunaan air pada pengolahan tahu cina 57 liter, pada pengolahan susu kedelai 38 liter dan pada pengolahan 38 liter.

\section{Persediaan Peralatan}

Proses pengolahan tidak lepas dari peralatan sehingga peralatan merupakan bagian yang sangat penting dalam membantu proses produksi di industri pengolahan hasil pertanian. Begitu juga industri Tiga Bersaudara mengunakan peralatan dalam pengolahan kedelai. Peralatan yang digunakan industri Tiga Bersauadara 
tergolong sangat sederhana. Sehingga menarik perhatian proses pengolahannya di teliti. Peralatan yang digunakan dalam pengolahan kedelai menjadi tahu cina, menjadi susu kedelai dan menjadi tahu gula hampir semua mengunakan peralatan yang sama. Peralatan yang disediakan pengolahan tiga produk yaitu Mesin, wajan, gas, dongkrat, ember, gayung, termos, sendok, kain sarwet, corong, mangkuk, pisau, cetakan dan papan mal. Peralatan yang digunakan bersama dihitung secara proposional. Nilai prosional didapatkan dari penjumlahan berat bersih santan kedelai dari tiga produk diatas kemudian berat masing-masing produk dibagi dengan total berat santan dari tiga produk tersebut kemudian dikalikan seratus. Maka hasil perhitungan proposinal adalah pada produk tahu cina 0,60 atau $60 \%$, pada produk susu kedelai 0,20 atau $20 \%$ dan pada produk tahu gula 0,20 atau $20 \%$.

\section{Biaya Pengolahan Kedelai Pada UD Tiga Bersaudara}

Pengolahan suatu produk ada biaya-biaya yang harus di keluarkan. Biasanya biaya tetap (fixed cost) dan biaya tidak tetap (variable cost). Biaya tetap adalah biaya relatif tetap jumlahnya dan terus dikeluarkan walaupun produksi banyak atau sedikit. Contohnya biaya bahan baku, biaya bahan penolong dan biaya penyusutan peralatan. Biaya tidak tetap adalah biaya yang besar kecilnya di pengaruhi oleh produksi yang di peroleh. Contohnya biaya tenaga kerja. Berikut ini biaya yang dikeluarkan pada pengolahan kedelai menjadi tahu cina, susu kedelai dan tahu gula.

\section{Biaya Pengolahan Tahu Cina}

Biaya yang di keluarkan tahu cina dapat di lihat pada Tabel 1.

\begin{tabular}{|c|c|c|c|c|}
\hline Nama Bahan & $\begin{array}{l}\text { Jumlah } \\
\text { Pemakaian }\end{array}$ & $\begin{array}{c}\text { Harga } \\
\text { (Rp) }\end{array}$ & $\begin{array}{l}\text { Jumlah } \\
\text { biaya } \\
\text { (Rp) }\end{array}$ & $\begin{array}{l}\text { Jumlah } \\
\text { Biaya } \\
\text { (Rp/Kg) }\end{array}$ \\
\hline $\begin{array}{l}\text { Bahan Baku : } \\
\text { Kedelai }\end{array}$ & $12 \mathrm{Kg}$ & 10.000 & 120.000 & 10.000 \\
\hline Sub total & & & 120.000 & 10.000 \\
\hline $\begin{array}{l}\text { Bahan Penolong } \\
\text { Batu tahu } \\
\text { Air }\end{array}$ & $\begin{array}{l}60 \text { Gram } \\
57 \text { Liter }\end{array}$ & $\begin{array}{r}12.000 \\
262\end{array}$ & $\begin{array}{r}7.200 \\
14.934\end{array}$ & $\begin{array}{r}600 \\
1.224,5\end{array}$ \\
\hline Sub total & & & 22.134 & $1.824,5$ \\
\hline Penyusutan Alat & & & & \\
\hline 1. Mesin giling & 1 & 5.000 .000 & 1.370 & 114 \\
\hline 2.Gas & 1 & 150.000 & 1.451 & 121 \\
\hline 3. Wajan & 2 & 800.000 & 1.315 & 110 \\
\hline 4. Kain peras & 2 & 17.000 & 9,32 & 78 \\
\hline 5. Papan mal & 2 & 70.000 & 31,96 & 2,66 \\
\hline 6. Ember & 2 & 65.000 & 106,85 & 890 \\
\hline 7. Gayung & 1 & 10.000 & 64,52 & 5,38 \\
\hline 8. Kain Sarwet & 2 & 15.000 & 96,77 & 8,06 \\
\hline 9. Pisau & 1 & 35.000 & 95,89 & 7,99 \\
\hline 10. Cetakan & 2 & 400.000 & 182,65 & 15,22 \\
\hline 11. Sendok & 1 & 12.000 & 20 & 1,67 \\
\hline Sub total & & & 4.887 & 422 \\
\hline Total biaya & & & 147.021 & $12.248,5$ \\
\hline
\end{tabular}

Tabel 1 menunjukkan bahwa biaya terbesar yang di keluarkan pada pengolahan tahu cina adalah biaya bahan baku yaitu sebesar $\mathrm{Rp}$. 120.000 atau jika hitung dalam satuan rupiah per $\mathrm{kg}$ yaitu sebesar Rp. 10.000,-/Kg. Biaya bahan baku terbesar karena bahan baku yang di gunakan dalam pengolahan tahu cina lebih besar dari pengunaan bahan baku pada produk lainnya. Biaya terbesar setelah bahan baku adalah biaya bahan penolong yaitu sebesar Rp. 22.134 atau dalam hitungan rupiah per kilogram yaitu sebesar Rp. 1.824, 5,-/Kg sedangkan biaya terendah yang di keluarkan pada pengolahan tahu cina adalah biaya penyusutan alat yaitu Rp. 4.887 atau dalam hitungan rupiah per kilogram yaitu sebesar Rp. 422,-/Kg. Biaya penyusutan alat terkecil karena biaya ini hanya sebagai biaya perawatan alat. Berdasarkan tabel 1 dapat di simpulkan total biaya pada pengolahan tahu cina yaitu sebesar Rp. 147.021 atau dalam hitungan $\mathrm{Rp} / \mathrm{Kg}$ yaitu sebesar Rp. 12. 248,5,-/Kg. Adapun rincian biaya tenaga kerja tahu cina dapat dilihat pada Tabel 2.

\begin{tabular}{lccrr}
\multicolumn{6}{c}{ Tabel 2 Rincian Biaya Tenaga Kerja Tahu Cina } \\
\hline $\begin{array}{c}\text { Jenis } \\
\text { Pekerjaan }\end{array}$ & $\begin{array}{c}\text { Lama } \\
\text { Pekerjaan }\end{array}$ & $\begin{array}{c}\text { Satuan } \\
\text { waktu }\end{array}$ & $\begin{array}{r}\text { Biaya } \\
\text { tenaga } \\
\text { kerja } \\
(\mathbf{R p})\end{array}$ & $\begin{array}{r}\text { Biaya } \\
\text { tenaga } \\
\text { kerja } \\
(\mathbf{R p} / \mathbf{K g})\end{array}$ \\
\hline Penjemuran & 1 & Jam & 18.750 & 1.563 \\
Pengilingan 1 & 20 & menit & 6.250 & 521 \\
Pentapisan & 15 & menit & $4.687,5$ & 390 \\
Perendaman & 30 & menit & 9.375 & 781 \\
Pengilingan 2 & 35 & menit & $10.937,5$ & 911 \\
Penyaringan & 15 & menit & $4.687,5$ & 390 \\
Pemasakan & 45 & menit & $14.062,5$ & 1.171 \\
Pemotongan & 10 & menit & 3.125 & 260 \\
Pengemasan & 10 & menit & 3.125 & 260 \\
\hline \multicolumn{1}{c}{ Jumlah } & \multicolumn{3}{c}{$\mathbf{7 5 . 0 0 0}$} & $\mathbf{4 . 6 8 6}$ \\
\hline
\end{tabular}

Tabel 2 menunjukkan bahwa biaya tenaga kerja yang terbesar pada pengolahan tahu cina adalah pada jenis pekerjaan penjemuran yaitu sebesar Rp. 18.750 atau jika dihitung dalam satuan rupiah per kilogram yaitu sebesar Rp. 1.563,-/Kg. Biaya pekerjaan penjemuran terbesar karena penjemuran butuh waktu lebih lama dari jenis perkerjaan lainnya supaya kacang kedelai benarbenar kering. Biaya tenaga kerja terbesar setelah penjemuran adalah pada jenis pekerjaan pemasakan yaitu sebesar Rp. 14.062,5 atau dalam satuan rupiah per kilogram yaitu sebesar Rp.1.171,-/Kg. Biaya pekerjaan pemasakan terbesar karena pemasakan butuh waktu cukup lama supaya santan kedelai benar-benar masak sedangkan biaya tenaga kerja terendah pada 
pengolahan tahu cina adalah pada jenis pekerjaan pemotongan dan pengemasan yaitu sebesar Rp. 3.125 atau dalam hitungan satuan per kilogram yaitu sebesar Rp.260,-/Kg. Total biaya tenaga kerja yang di keluarkan pada pengolahan tahu cina yaitu sebesar Rp. 75.000 atau dalam satuan rupiah per kilogram sebesar Rp. 4.686,-/Kg. Tenaga kerja yang di gunakan UD. Tiga Bersaudara pada pengolahan tahu cina adalah tenaga kerja keluarga yang terdiri dari dua orang anggota keluarga. Biaya tenaga kerja pada Tabel 2 dihitung sesuai HOK (hari orang kerja) yaitu Rp. 150.000/8 jam.

\section{Biaya Pengolahan Susu Kedelai}

Biaya yang keluarkan pada pengolahan susu kedelai dapat dilihat pada Tabel 3.

\begin{tabular}{|c|c|c|c|c|}
\hline $\begin{array}{l}\text { Nama } \\
\text { Bahan }\end{array}$ & $\begin{array}{c}\text { Jumlah } \\
\text { pemakaian }\end{array}$ & $\begin{array}{c}\text { Harga } \\
\text { (Rp) }\end{array}$ & $\begin{array}{c}\text { Jumlah } \\
\text { Biaya } \\
\text { (Rp) }\end{array}$ & $\begin{array}{c}\text { Jumlah } \\
\text { Biaya } \\
(\mathbf{R p} / \mathbf{K g})\end{array}$ \\
\hline \multicolumn{5}{|l|}{ Bahan baku } \\
\hline Kedelai & $3 \mathrm{Kg}$ & 10.000 & 30.000 & 10.000 \\
\hline Sub total & & & 30.000 & 10.000 \\
\hline \multicolumn{5}{|l|}{ Bahan penolong } \\
\hline 1. Gula putih & $1 \mathrm{Kg}$ & 12.000 & 12.000 & 4.000 \\
\hline 2. Daun pandan & 1 Ikat & 2.000 & 2.000 & 667 \\
\hline 3. Air & 38 Liter & 262 & 9.956 & 3.319 \\
\hline Sub total & & & 23.956 & 7.985 \\
\hline \multicolumn{5}{|l|}{ Penyusutan Alat } \\
\hline $\begin{array}{l}\text { 1. Mesin } \\
\text { giling }\end{array}$ & 1 & 5.000 .000 & 456,62 & 152 \\
\hline 2. Wajan & 2 & 800.000 & 438,36 & 142 \\
\hline 3. Gas & 1 & 150.000 & 483,87 & 161 \\
\hline 4. Ember & 1 & 65.000 & 35,62 & 11,87 \\
\hline 5.Corong & 1 & 5.000 & 714,28 & 238 \\
\hline 6. Dongkrat & 1 & 260.000 & 47,48 & 15,83 \\
\hline 7.Gayung & 1 & 10.000 & 21,50 & 7,17 \\
\hline 8.Saringan & 1 & 17.000 & 9,32 & 3,11 \\
\hline 9. Mangkuk & 1 & 10.000 & 1.429 & 476 \\
\hline 10. Sendok & 1 & 5.000 & 6,58 & 2,19 \\
\hline Sub total & & & 3.642 & 1,209 \\
\hline Total biaya & & & 57.598 & 18.402 \\
\hline
\end{tabular}

Tabel 3 menunjukkan bahwa biaya yang terbesar yang keluarkan UD Tiga Bersaudara pada pengolahan susu kedelai adalah biaya bahan baku yaitu sebesar Rp. 30.000 atau jika dihitung dalam satuan rupiah per kilogram yaitu sebesar Rp. 10.000,-/Kg. Biaya terbesar setelah biaya bahan baku adalah biaya bahan penolong yaitu sebesar Rp. 23.956 atau dalam hitungan satuan rupiah per kilogram yaitu sebesar Rp. 7.985,-/Kg sedangkan biaya yang terendah pada pengolahan susu kedelai adalah biaya penyusutan alat yaitu sebesar Rp. 3.642 atau dihitung dalam satuan rupiah per kilogram yaitu sebesar Rp. 1.209,-/Kg. Pada Tabel 3 dapat di simpulkan bahwa total biaya yang keluarkan UD Tiga Bersaudara pada proses pengolahan susu kedelai yaitu sebesar Rp. 57.598 atau dalam satuan rupiah per kilogram yaitu sebesar Rp. 18.402,-/Kg. Rincian Biaya Tenaga Kerja Susu Kedelai dapat dilihat pada Tabel 4.

\begin{tabular}{lccrr}
\multicolumn{6}{c}{ Tabel 4. Rincian Biaya Tenaga Kerja Susu Kedelai } \\
\hline $\begin{array}{c}\text { Jenis } \\
\text { Pekerjaan }\end{array}$ & $\begin{array}{c}\text { lama } \\
\text { Pekerjaan }\end{array}$ & $\begin{array}{c}\text { Satua } \\
\mathbf{n}\end{array}$ & $\begin{array}{r}\text { Biaya } \\
\text { Tenaga } \\
\text { Kerja } \\
(\mathbf{R p )})\end{array}$ & $\begin{array}{r}\text { Biaya } \\
\text { Tenaga } \\
\text { Kerja } \\
(\mathbf{R p} / \mathbf{K g})\end{array}$ \\
\hline Penjemuran & 1 & Jam & 18.750 & 6.250 \\
Pengilingan 1 & 15 & Menit & $4.687,5$ & 1.562 \\
Pentapisan & 10 & Menit & 3.125 & 1.042 \\
Perendaman & 30 & Menit & 9.375 & 3.125 \\
Pengilingan 2 & 25 & Menit & $7.812,5$ & 2.604 \\
Penyaringan & 5 & Menit & $1.562,5$ & 521 \\
Pemasakan & 30 & Menit & 9.375 & 3.125 \\
Pengemasan & 20 & Menit & 6.210 & 204 \\
\hline \multicolumn{1}{c}{ Jumlah } & & & $\mathbf{6 0 . 9 3 7 , 5}$ & $\mathbf{1 8 . 4 3 3}$ \\
\hline
\end{tabular}

Tabel 4 menunjukkan bahwa biaya tenaga kerja yang terbesar adalah pada jenis pekerjaan penjemuran yaitu sebesar Rp. 18.750 atau dalam hitungan satuan rupiah per kilogram yaitu sebesar Rp. 6.250,-/Kg. Biaya tenaga kerja terbesar setelah penjemuran adalah pada jenis pekerjaan perendaman dan pemasakan yaitu sebesar Rp. 9.375 atau dalam satuan rupiah per kilogram yaitu sebesar Rp. $3.125,-/ \mathrm{Kg}$ sedangkan biaya tenaga kerja terendah adalah pada jenis pekerjaan penyaringan yaitu sebesar 1.562,5 atau dalam satuan rupiah per kilogram yaitu sebesar Rp.521,-/Kg. Pada Tabel 4 dapat di simpulkan bahwa total biaya tenaga kerja yang di keluarkan pada pengolahan susu kedelai sebesar Rp.60.937,5 atau dalam satuan rupiah per kilogram sebesar Rp. 18.443,-/Kg. Berdasarkan perhitungan pada Tabel 4 diatas, biaya tenaga kerja dihitung sesuai HOK (hari orang kerja) yaitu Rp. 150.000/8 jam. Jadi cara perhitungannya adalah lama pekerjaan dikalikan Rp 150.000 kemudian dibagi 8.

\section{Biaya Pengolahan Tahu Gula}

Biaya yang di keluarkan pada pengolahan tahu gula dapat di lihat pada Tabel 5 . 


\begin{tabular}{|c|c|c|c|c|}
\hline Nama Bahan & $\begin{array}{c}\text { Jumlah } \\
\text { Pemakian }\end{array}$ & $\begin{array}{c}\text { Harga } \\
\text { (Rp) }\end{array}$ & $\begin{array}{c}\text { Jumlah } \\
\text { Biaya } \\
\text { (Rp) }\end{array}$ & $\begin{array}{c}\text { Jumlah } \\
\text { biaya } \\
\text { (Rp/Kg) }\end{array}$ \\
\hline $\begin{array}{l}\text { Bahan Baku } \\
\text { Kedelai }\end{array}$ & $3 \mathrm{Kg}$ & 10.000 & 30.000 & 10.000 \\
\hline Sub total & & & 30.000 & 10.000 \\
\hline $\begin{array}{l}\text { Bahan Penolong } \\
\text { 1. Jahe } \\
\text { 2. Gula Merah } \\
\text { 3. Batu Tahu } \\
\text { 4. Air }\end{array}$ & $\begin{array}{c}1 \mathrm{Kg} \\
2 \mathrm{Kg} \\
36 \mathrm{Gram} \\
38 \mathrm{Liter}\end{array}$ & $\begin{array}{c}70.000 \\
30.000 \\
12.000 \\
262 \\
\end{array}$ & $\begin{array}{c}70.000 \\
60.000 \\
4.320 \\
9.956 \\
\end{array}$ & $\begin{array}{c}23.333 \\
20.000 \\
1.440 \\
3.319 \\
\end{array}$ \\
\hline Sub total & & & 144.276 & 48.092 \\
\hline $\begin{array}{l}\text { Penyusutan Alat } \\
\text { 1. Mesin giling } \\
\text { 2. Wajan } \\
\text { 3. Sendok } \\
\text { 4. Termos } \\
\text { 5. Penyaring } \\
\text { 6. Ember } \\
\text { 7. Gas } \\
\text { 8. Gayung } \\
\text { 9. Dongkrat } \\
\end{array}$ & $\begin{array}{l}1 \\
2 \\
1 \\
1 \\
1 \\
1 \\
1 \\
1 \\
1 \\
\end{array}$ & $\begin{array}{c}5.000 .000 \\
800.000 \\
12.000 \\
130.000 \\
17.000 \\
65.000 \\
150.000 \\
10.000 \\
260.000 \\
\end{array}$ & $\begin{array}{c}456,62 \\
438,36 \\
6,58 \\
1.398 \\
9,32 \\
35,62 \\
483,87 \\
21,50 \\
47,48 \\
\end{array}$ & $\begin{array}{c}152 \\
142 \\
2,19 \\
466 \\
3,11 \\
11,87 \\
161 \\
7,17 \\
15,83 \\
\end{array}$ \\
\hline \begin{tabular}{|l|} 
Sub total \\
Total biaya \\
\end{tabular} & & & \begin{tabular}{|c|}
2.897 \\
177.173 \\
\end{tabular} & \begin{tabular}{|c|}
921 \\
59.802 \\
\end{tabular} \\
\hline
\end{tabular}

Tabel 5 menunjukkan bahwa biaya yang terbesar yang keluarkan UD Tiga Bersaudara pada proses pengolahan tahu gula adalah biaya bahan penolong yaitu sebesar Rp. 144.276 atau dihitung dalam satuan rupiah per kilogram yaitu sebesar Rp. 48.092,-/Kg. Biaya bahan penolong tahu gula terbesar karena bahan penolong yang digunakan lebih banyak dan harga dari bahan penolong tersebut lebih besar. Biaya terbesar setelah biaya bahan penolong adalah biaya bahan baku yaitu sebesar Rp. 30.000 atau dalam hitungan satuan rupiah per kilogram yaitu sebesar Rp. 10.000,-/Kg sedangkan biaya yang terendah pada proses pengolahan tahu gula adalah biaya penyusutan alat yaitu sebesar Rp. 2.897 atau dalam hitungan rupiah per kilogram yaitu sebesar Rp. 921,-/Kg. Berdasarkan Tabel 5 dapat di simpulkan bahwa total biaya yang di keluarkan UD Tiga Bersaudara pada proses pengolahan tahu gula sebesar Rp. 177.173 atau dalam rupiah per kilogram sebesar Rp. 59.802,$/ \mathrm{Kg}$.

\begin{tabular}{lccrr}
\multicolumn{6}{c}{ Tabel 6 Rincian Biaya Tenaga Kerja Tahu Gula } & \\
\hline $\begin{array}{c}\text { Jenis } \\
\text { Pekerjaan }\end{array}$ & $\begin{array}{c}\text { lama } \\
\text { Pekerjaan }\end{array}$ & Satuan & $\begin{array}{r}\text { Biaya } \\
\text { Tenaga } \\
\text { Kerja } \\
(\mathbf{R p )}\end{array}$ & $\begin{array}{r}\text { Biaya } \\
\text { Tenaga } \\
\text { Kerja } \\
(\mathbf{R p} / \mathbf{K g})\end{array}$ \\
\hline Penjemuran & 1 & Jam & 18.750 & 6.250 \\
Pengilingan 1 & 15 & menit & 4.687 & 1.562 \\
Pentapisan & 5 & menit & 1.562 & 521 \\
Perendaman & 30 & menit & 9.375 & 3.125 \\
Pengilingan 2 & 25 & menit & 7.812 & 2.604 \\
Penyaringan & 5 & menit & 1.562 & 521 \\
Pemasakan & 30 & menit & 9.375 & 3.125 \\
Pengemasan & 5 & menit & 1.562 & 521 \\
\hline Total & & & $\mathbf{5 4 . 6 8 7 , 5}$ & $\mathbf{1 8 . 2 2 9}$ \\
\hline
\end{tabular}

Tabel 6 menunjukkan bahwa biaya tenaga kerja yang terbesar pada proses pengolahan tahu gula adalah pada jenis pekerjaan penjemuran yaitu sebesar Rp. 18.750 atau dalam rupiah per kilogram Rp.6.250,-/Kg. Biaya tenaga kerja terbesar setelah penjemuran adalah pada jenis pekerjaan perendaman dan pemasakan dengan biaya sebesar Rp. 9.375 atau dalam satuan rupiah per kilogram sebesar Rp. 3.125,-/Kg sedangkan biaya tenaga kerja yang terendah pada proses pengolahan tahu gula adalah penyaringan dan pengemasan yaitu sebesar Rp. 1.562 atau dalam satuan rupiah per kilogram sebesar Rp. 152,-/Kg. Pada Tabel 6 dapat di simpulkan bahwa total biaya yang di keluarkan pada pengolahan tahu gula sebesar Rp. 54.687,5 atau dalam satuan rupiah per kilogram sebesar Rp. 18.229,-/Kg Berdasarkan perhitungan pada Tabel di atas, biaya tenaga kerja dihitung sesuai HOK (hari orang kerja) yaitu Rp. 150.000/8 jam.

\section{Perhitungan Nilai Akhir}

Nilai akhir adalah Penerimaan suatu produk yang di dapatkan dari jumlah produk yang di hasilkan (Q) dikali dengan harga produk (P). Penerimaan produk dari tahu cina, susu kedelai dan tahu gula dapat pada Tabel 7.

\begin{tabular}{cccccc}
\multicolumn{6}{c}{ Tabel 7. Rincian Penerimaan Produk UD Tiga Bersaudara } \\
\hline $\begin{array}{c}\text { Nama } \\
\text { Produk Produksi }\end{array}$ & Satuan & $\begin{array}{c}\text { Harga } \\
\text { Produk } \\
(\mathbf{R p})\end{array}$ & $\begin{array}{c}\text { Total } \\
\text { Penerimaan } \\
(\mathbf{R p})\end{array}$ & $\begin{array}{c}\text { Total } \\
\text { Penerimaan } \\
(\mathbf{R p} / \mathbf{K g})\end{array}$ \\
\hline $\begin{array}{c}\text { Tahu } \\
\text { Cina }\end{array}$ & 200 & Potong & 3.000 & 600.000 & 50.000 \\
$\begin{array}{c}\text { Susu } \\
\text { Kedelai } \\
\text { Tahu } \\
\text { Gula }\end{array}$ & 30 & Plastik & 5.000 & 150.000 & 50.000 \\
\hline
\end{tabular}

Tabel 7 menunjukkan bahwa jumlah produksi tahu cina jauh lebih banyak dari produk lainnya karena, pada proses pengolahan bahan baku yang di gunakan tahu cina lebih banyak dari pengolahan produk lainnya sedangkan produk susu kedelai dengan tahu gula jumlah produksinya sama tetapi kemasannya berbeda. Berdasarkan hasil penelitian harga produk yang tertinggi adalah tahu gula dimana harga per 1 gelasnya Rp. 10.000. Berdasarkan Tabel 7 dapat di simpulkan bahwa penerimaan tahu cina sebesar Rp. 600.000, penerimaan susu kedelai sebesar Rp. 150.000 dan penerimaan tahu gula sebesar 300.000. Jika di hitung dalam satuan rupiah per kilogram total penerimaan yang 
terbesar adalah pada produk tahu gula yaitu sebesar Rp. 100.000,-/Kg sedangkan total penerimaan susu kedelai yang terbesar setelah penerimaan tahu gula adalah produk susu kedelai dan produk tahu gula karena jumlah penerimaannya sama yaitu sebesar Rp. $50.000,-/ \mathrm{Kg}$.

\section{Perhitungan Nilai Tambah}

Nilai tambah adalah pertambahan nilai dari suatu produk karena telah mengalamai proses pengolahan, pengangkutan dan penyimpanan. Nilai tambah didapat dari nilai akhir di kurangan dengan biaya antara. Nilai akhir adalah penerimaan produk sedangkan biaya antara terdiri dari biaya bahan baku, bahan penolong dan biaya penyusutan peralatan. Hasil perhitungan nilai tambah dapat dilihat pada Tabel 8.

Tabel 8 Perbandingan Nilai Tambah Produk Pada UD

\begin{tabular}{llrrr}
\multicolumn{1}{c}{ Tiga Bersaudara } & \multicolumn{1}{c}{ Uraian } & \multicolumn{1}{c}{$\begin{array}{c}\text { Tahu } \\
\text { Cina }\end{array}$} & $\begin{array}{c}\text { Susu } \\
\text { Kedelai }\end{array}$ & \multicolumn{1}{c}{$\begin{array}{c}\text { Tahu } \\
\text { Gula }\end{array}$} \\
\hline 1. & $\begin{array}{l}\text { Nilai Akhir }(\mathrm{Rp} / \mathrm{Kg}) \\
\text { Biaya Bahan baku } \\
\text { (Rp/Kg) }\end{array}$ & 50.000 & 50.000 & 100.000 \\
3. & $\begin{array}{l}\text { Biaya Bahan Penolong } \\
\text { (Rp/Kg) }\end{array}$ & $1.824,5$ & 10.000 & 10.000 \\
4. & 7.985 & 48.092 \\
Biaya Penyusutan & 422 & 1.209 & 921 \\
Peralatan $(\mathrm{Rp} / \mathrm{Kg})$ & Nilai Tambah $(\mathrm{Rp} / \mathrm{Kg})$ & 38.354 & 30.806 & 40.987 \\
\hline
\end{tabular}

Tabel 8 menunjukkan bahwa nilai tambah yang tertinggi adalah pada pengolahan kedelai menjadi tahu gula yaitu sebesar Rp. 40.987,-/Kg. Nilai tambah produk tahu gula pada UD Tiga Bersaudara tertinggi di sebabkan karena mempunyai keunggulan dari segi kemasan dan harga sehingga mempengaruhi nilai tambah produk meningkat. Tetapi produk tahu gula hanya bertahan dalam satu hari. Nilai tertinggi setelah produk tahu adalah pada pengolahan tahu cina yaitu sebesar Rp. 38.354,-/Kg. Tahu cina mempunyai keunggulan pada ketahanan produknya. Berdasarkan informasi yang di dapatkan dari pemilik usaha pengolahan produk tahu cina bertahan dua sampai tiga hari. Nilai tambah yang terendah adalah pada pengolaha kedelai menjadi susu kedelai yaitu sebesar $\mathrm{Rp}$. $30.806,-/ \mathrm{Kg}$. Nilai tambah terendah disebakan karena produk susu kedelai masih mengunakan kemasan yang sederhana dan harga produknya lebih rendah dari susu kedelai pada umumya sehingga masalah tersebut dapat menyebabkan nilai dari produk susu kedelai rendah. Berdasarkan analisis nilai tambah di atas dapat di simpulkan bahwa nilai tambah yang tertinggi di UD Tiga Bersaudara adalah pada pengolahan tahu gula.

\section{Perhitungan Keuntungan}

Keuntungan adalah merupakan selisih antara pendapatan dan penerimaan dan pengeluaran total biaya. Rumus yang biasa digunakan dalam menghitung keuntungan yaitu $\pi=\mathrm{TR}-\mathrm{TC}$. Tetapi perhitungan keuntungan pada pengolahan produk kedelai pada UD Tiga Bersaudara di hitung dengan rumus $\pi=\mathrm{Na}-\mathrm{Ba}-\mathrm{Tk}$ atau $\pi=\mathrm{NT}-\mathrm{Tk}$. Adapun perhitungan keuntungan untuk pengolahan kedelai tahu cina, susu kedelai dan tahu gula dapat di lihat pada Tabel 9.

Tabel 9. Perhitungan Keuntungan Produk UD Tiga

\begin{tabular}{|c|c|c|c|}
\hline $\begin{array}{l}\text { Nama } \\
\text { Produk }\end{array}$ & $\begin{array}{c}\text { Nilai } \\
\text { Tambah } \\
\text { (Rp/Kg) }\end{array}$ & $\begin{array}{c}\text { Biaya } \\
\text { Tenaga } \\
\text { Kerja } \\
(\mathbf{R p} / \mathbf{K g}) \\
\end{array}$ & $\begin{array}{c}\text { Keuntungan } \\
\text { (Rp/Kg) }\end{array}$ \\
\hline Tahu cina & 38.354 & 4.686 & 33.668 \\
\hline Susu kedelai & 30.806 & 18.443 & 12.363 \\
\hline Tahu gula & 40.987 & 18.227 & 22.758 \\
\hline
\end{tabular}

Tabel 9 menunjukkan bahwa keuntungan yang terbesar adalah pada pengolahan kedelai menjadi tahu cina yaitu sebesar Rp. 33.668,-/Kg. Keuntungan produk tahu cina terbesar karena biaya yang di keluarkan pada proses pengolahan tahu cina lebih kecil dari proses pengolahan susu kedelai dan tahu gula. Keuntungan terbesar setelah produk tahu cina adalah pada pengolahan kedelai menjadi tahu gula yaitu sebesar Rp. $22.758,-/ \mathrm{Kg}$ dan keuntungan terendah adalah pada pengolahan kedelai menjadi susu kedelai yaitu sebesar Rp. 12.363,-/Kg. Keuntungan susu kedelai terendah karena biaya yang keluarkan dalam proses pengolahan tidak seimbang dengan penerimaan yang di hasilkan. Maka keuntungan susu kedelai lebih rendah dari produk lainnya. 


\section{KESIMPULAN DAN SARAN}

\section{Kesimpulan}

Nilai tambah dari pengolahan kedelai menjadi tahu cina Rp. 38.354,/Kg. Nilai tambah dari pengolahan kedelai menjadi susu kedelai sebesar. Rp. $30.806,-/ \mathrm{Kg}$ dan nilai tambah dari pengolahan kedelai menjadi tahu gula sebesar Rp. 40.987,-/Kg.

Keuntungan dari pengolahan kedelai menjadi tahu cina sebesar Rp. 33.668,/Kg. Keuntungan pengolahan kedelai menjadi susu kedelai sebesar Rp. 12.363,-/Kg dan keuntungan dari pengolahan kedelai menjadi tahu gula sebesar Rp. 22.758,-/Kg.

Nilai tambah pengolahan kedelai menjadi tahu gula lebih tinggi dari nilai tambah usaha pengolahan kedelai menjadi tahu cina dan susu kedelai. Pada keuntungan, pengolahan kedelai menjadi tahu cina lebih tinggi dari keuntungan usaha pengolahan kedelai menjadi tahu gula dan susu kedelai. Dari kesimpulan di atas dapat disimpulkan bahwa tidak selamanya nilai tambah tertinggi mendapatkan keuntungan tertinggi dan tidak selamanya keuntungan tertinggi mendapatkan nilai tambah tertinggi.

\section{Saran}

Saran yang dapat berikan adalah untuk produk tahu cina pertahankan kualitas produknya dan buat kemasan produk supaya selain mendapatkan keuntungan juga nilai tambah produk meningkat. Pada produk susu kedelai disarankan buat kemasan produk yang menarik pada produk tersebut supaya harga produk meningkat, nilai tambah meningkat dan keuntungan juga meningkat. Pada produk tahu gula disarankan pertahankan juga kuliatas produknya dan perluas pemasaranya supaya mendapat keuntungan yang maksimal.

\section{DAFTAR PUSTAKA}

Adisarwano, T. 2005. Bertanam Kedelai. Penebar Swadaya, Jakarta.

Lipsey, G.R., Peter, O. S. dan Douglas, D. P.1990. Pengantar Mikroekonomi 1 Jilid I. Jakarta: Erlangga.

Sicat, G. P., \& Arndt, H. W. 1991. Ilmu ekonomi: untuk konteks Indonesia. Lembaga Penelitian, Pendidikan dan Penerangan Ekonomi dan Sosial.

Soekartawi. 1995. Analisis Usahatani. Penerbit Univertas Indonesia. UI Press. Jakarta.

Zulkifli. 2012. Analisis pendapatan dan nilai tambah pada agroindustri keripik ubi Di Kecamatan Tanah Luas Kabupaten Aceh Utara. Skripsi. Fakultas Pertanian Universitas Malikussaleh. Aceh Utara. 